\title{
Expanded memory CD4+ T Cells in the fetal and the infant Gut; a mucosal route for mother-to-child transmission of HIV-1
}

MJ Bunders ${ }^{*}$, C van der Loos, PL Klarenbeek, J van Hamme, J Wilde, N de Vries, RA van Lier, N Kootstra, ST Pals, TW Kuijpers

From AIDS Vaccine 2012

Boston, MA, USA. 9-12 September 2012

\section{Background}

Cord blood-derived CD4+ T cells have a naïve phenotype and do not express CCR5, the mandatory co-receptor for transmitted HIV-1 R5 strains in infants. This leaves the question unanswered: what are the target cells for MTCT of HIV-1 and where do they reside? We hypothesized that in infant mucosal tissues, CD4+CCR5 $+\mathrm{T}$ cells may be present to facilitate mucosal transmission of HIV-1.

\section{Methods}

Using multicolor immuno-histochemistry, flowcytometry and next-generation sequencing of the $\mathrm{T}$ cell receptor, we analyzed various human fetal and infant tissues to identify memory CD4+ T cells as targets for HIV-1.

\section{Results}

Here, we demonstrate the previously unrecognized abundance of memory CD4+CCR5+ T cells in the human fetal and infant gut mucosa. CD4+ T cells from mesenteric lymph node were mostly naïve, similar to blood. $\mathrm{T}$ helper differentiation profiles as determined by transcription factors differed by tissue, with T-bet and ROR $\gamma$ t predominantly expressed by memory $\mathrm{T}$ cells in the gut mucosa. Next-generation sequencing for high-resolution screening of the T-cell receptor $\beta$-chain repertoire of clonal $\mathrm{T}$ cells as a hallmark of memory cells, identified expanded $\mathrm{T}$ cell clones in the gut mucosa $(30 \%)$ and not in lymph node or cord blood. The gut mucosal fetal and infant CD4+ T cells were extremely susceptible to HIV-1 without any prestimulation; pol proviral DNA levels were similar to infected PHA stimulated adult PBMCs.

\section{Conclusion}

In conclusion, we show that extensive adaptive immunity, with a tissue-depended distribution is present before birth, resulting in the gut mucosa as the preferential site for memory CD4+ T cells. These memory CD4+CCR5+T cells provide a large pool of susceptible cells for ingested HIV-1 at birth and during breastfeeding, indicating a mucosal route of MTCT of HIV-1, which can be targeted in future prevention strategies.

Published: 13 September 2012

doi:10.1186/1742-4690-9-S2-O21

Cite this article as: Bunders et al:: Expanded memory CD4+ T Cells in the fetal and the infant Gut; a mucosal route for mother-to-child transmission of HIV-1. Retrovirology 2012 9(Suppl 2):O21.

Submit your next manuscript to BioMed Central and take full advantage of:

- Convenient online submission

- Thorough peer review

- No space constraints or color figure charges

- Immediate publication on acceptance

- Inclusion in PubMed, CAS, Scopus and Google Scholar

- Research which is freely available for redistribution

Academic Medical Centre, Amsterdam, the Netherlands 